\title{
Landforms characteristic of inter-ice stream settings on the Norwegian and Svalbard continental margins
}

\author{
J. A. DOWDESWELL ${ }^{1 *}$, D. OTTESEN ${ }^{2} \&$ L. RISE ${ }^{2}$ \\ ${ }^{1}$ Scott Polar Research Institute, University of Cambridge, Cambridge CB2 1ER, UK \\ ${ }^{2}$ Geological Survey of Norway, Postboks 6315 Sluppen, N-7491 Trondheim, Norway \\ *Corresponding author (e-mail: jd16@cam.ac.uk)
}

\begin{abstract}
The suite of sedimentary landforms produced on continental shelves by fast-flowing ice streams is typified by features that are elongate and streamlined in the direction of past ice flow (e.g. Stokes \& Clark 2001; Ottesen et al. 2005a; Livingstone et al. 2012). By contrast, slower-flowing parts of an ice-sheet, located between ice streams and fed by drainage basins that are often an order of magnitude or more smaller than the interior basins feeding ice-stream, have a very different set of characteristic submarine landforms which are orientated predominantly transverse to the direction of past ice flow (Ottesen \& Dowdeswell 2009; Klages et al. 2013, 2016). In addition, on many high-latitude shelf-banks, glacial landforms produced beneath and at the margins of ice sheets are often reworked by the ploughing action of iceberg keels, sometimes to the point where these primary depositional landforms are almost obliterated (e.g. Dowdeswell et al. 1993, 2014).

Submarine landforms from the western margin of the former Eurasian Ice Sheet, which extended across the shallow banks and deeper intervening troughs on the continental shelves of Norway and Svalbard at the Last Glacial Maximum (LGM) (Svendsen et al. 2004; Ottesen et al. 2005a), are used to illustrate this inter-ice stream palaeo-glacial setting (Fig. 1). In these locations, ice flux is limited by relatively small drainage-basin size and ice flow is likely to be slow relative to the $10^{3}$ to $10^{4} \mathrm{~m} \mathrm{yr}^{-1}$ velocities of adjacent ice streams (Dowdeswell \& Siegert 1999).
\end{abstract}

\section{Inter-trough banks on continental shelves}

\section{Description}

The continental shelves off Norway and Svalbard are characterised in broad-scale morphology by a series of relatively shallow banks, often fairly uniform in water depth, separated by deep cross-shelf troughs (Fig. 1) (Ottesen et al. 2005a; Batchelor \& Dowdeswell 2014). Such relatively shallow and low-gradient areas around 200-300 m deep on the Norwegian shelf include Røstbanken, Trænabanken and Haltenbanken (Fig. 1b). A similar morphology of cross-shelf troughs (up to $350 \mathrm{~m}$ deep) and shallower inter-trough banks (often $<150 \mathrm{~m}$ deep) is found west and north of Svalbard (Fig. 1c), but here the banks are less clearly developed due to the narrower width of the shelf relative to that west of Norway (Ottesen et al. 2005a).

\section{Interpretation}

A Late Weichselian ice sheet covered both Norway and Svalbard, and filled the intervening Barents Sea, about 18,000 years ago, extending to the shelf edge along the entire western and northern margin of the ice sheet (Svendsen et al. 2004; Ottesen et al. 2005a; Hughes et al. 2016). On the continental shelf, the ice sheet was differentiated into fast- and slow-flowing elements (Ottesen et al. 2005a), the former known as ice streams (e.g. Clarke 1987). The ice streams, which occupied and eroded the cross-shelf troughs (Batchelor \& Dowdeswell 2014), drained the bulk of the interior of the parent ice sheet, as they do in Antarctica and Greenland today, where they account for up to about $80 \%$ of mass loss at the marine margins (e.g. Bamber et al. 2000; Rignot \& Kanagaratnam 2006).

By contrast, the intervening shallow banks between palaeo-ice streams were fed from much smaller drainage basins, especially after fast flow was initiated in cross-shelf troughs as the ice sheet built up, causing down-draw from interior ice-sheet drainage basins.

An example of an inter-ice stream area is the northwest Svalbard shelf, between Kongsfjorden-Krossfjorden glacier system to the south and Woodfjorden-Wijdefjorden system to the north-east (Fig. 1c). This shelf area has a drainage basin of $<900 \mathrm{~km}^{2}$, contrasting with 3,000 and 7,500 $\mathrm{km}^{2}$ basins for the two ice-stream systems (Ottesen \& Dowdeswell 2009). Similarly, on the Norwegian margin, the ice stream occupying the major trough complex of Trænadjupet and Vestfjorden at the LGM (Fig. 1b) drained an interior basin of about $150,000 \mathrm{~km}^{2}$ (Ottesen et al. 2005b), which is an order of magnitude greater than the basin feeding the much shallower Trænabanken to the south (Ottesen et al. 2005a). The shallow shelf-banks were, therefore, covered by slow-flowing ice that may, where it was relatively thin, have been frozen to the substrate for at least part of the Late Weichselian glaciation.

\section{Landforms on the outermost shelf and upper slope}

\section{Description}

In several areas of the outermost shelf offshore of Svalbard and Norwegian banks, two characteristic submarine landforms are present at or close to the shelf break (Fig. 2). These are sedimentary ridges (Dowdeswell \& Elverhøi 2002; Ottesen \& Dowdeswell 2009) and, in some places, hummocky terrain in a belt one to a few kilometres in width (Ottesen \& Dowdeswell 2009; Elvenes \& Dowdeswell 2016). The shelf-edge ridges are variable in height, at up to a few tens of metres, and can extend along the shelf for tens of kilometres (Fig. 2). They are sometimes found together with the hummocky terrain (Fig. 2).

The hummocky terrain has irregular crests and depressions of amplitude 5-20 m that extend in well-defined belts for tens of kilometres along the shelf edge offshore of shallow banks on both the northwest Svalbard and north Norwegian shelf (Fig. 2) (Ottesen \& Dowdeswell 2009; Elvenes \& Dowdeswell 2016). The crests tend to be orientated sub-parallel to the shelf edge and are usually asymmetrical, with steeper seaward faces.

On the outermost shelf and upper slope, immediately beyond the shelf edge, several further types of sedimentary submarine landform are identified (Fig. 3). Curvilinear scour-like depressions, tens to thousands of metres in length, are found in a chaotic pattern on the outermost shelf, with this pattern changing to mainly shelf-parallel depressions on the uppermost slope (Fig. 3). In addition, there is evidence of downslope sediment transfer in the form of glacigenic-debris flows, shallow scars and mass-wasting deposits on the uppermost slope (Fig. 3b). These features occasionally appear to cross-cut the curvilinear depressions. 


\section{Interpretation}

Well-defined ridges at the shelf edge are interpreted as shelf-edge moraines, produced at grounded and relatively slow-flowing ice-sheet termini (Dowdeswell \& Elverhøi 2002). Ice flux to such inter-ice stream margins was probably insufficient to sustain a floating ice shelf, given that iceberg calving rate would increase substantially in the deepening water of the upper slope (Benn et al. 2007). Sediment-ridge building also requires the vertical accommodation space that is present at a grounded terminus but is unavailable at an ice shelf grounding-zone (Batchelor \& Dowdeswell 2015).

The undulating topography of the belts of hummocky terrain (Fig. 2), produced when the ice-sheet terminated at the shelf edge during full-glacials, may be explained by buoyancy related tidally driven variations in grounding-zone position, which have been observed beneath modern ice-shelf grounding-zones (Bindschadler et al. 2003; Gudmundsson 2006). Asymmetry in crest cross-section may be due to differences in proximal to distal ice loading of subglacial sediment close to the ice margin during these tidal oscillations (Christianson et al. 2013). Hence, the term 'lift-off' moraine has been suggested for these hummocky moraine belts (Elvenes \& Dowdeswell 2016).

The curvilinear scour-like depressions of varying length and width, together with the pits located around the shelf edge, are interpreted as ploughmarks and pits produced by the grounding of iceberg keels (Figs. 2d, 3). Iceberg drift appears largely chaotic on the outermost shelf-banks but, in the deepening water beyond the shelf break, a number of ploughmarks are orientated sub-parallel to the shelf edge (Fig. 3a). This suggests that the shelf-edge may have prevented deeper-keeled icebergs from accessing the outer shelf and that iceberg drift is likely to have been northwards in the prevailing currents offshore of western Norway and Svalbard. Beyond the shelf edge, the upper slope appears affected by mass-wasting activity in the form of debris flows and slides (Fig. 3).

\section{Landforms on inter-trough banks}

\section{Description}

Among the most commonly identified landforms on the shallow banks between ice streams are series of small ridges, typically a few metres in height above the surrounding seafloor, aligned at right-angles to the direction of past ice flow (Fig. 4a-b). These transverse-toflow ridges are found in groups of tens and sometimes hundreds, orientated sub-parallel to one another and usually spaced about 50-250 $\mathrm{m}$ apart, on the banks of the mid-Norwegian shelf and offshore of NW Svalbard (Ottesen et al. 2005a; Ottesen \& Dowdeswell 2009). Occasionally, subdued sedimentary lineations, orientated in the direction of past ice flow, are present on the shelf and are cross-cut by the transverse ridges (Ottesen \& Dowdeswell 2009).

In a number of places on the banks between cross-shelf troughs there are also indications that the transverse-to-flow ridges have been reworked subsequently by iceberg-keel ploughing (Fig. 4a, c) and the action of currents (Fig. 4d), and through more minor disturbance by gas or fluid escape and the formation of associated pockmarks (Fig. 4a). In some places ploughing by iceberg keels has almost completely reworked and obliterated these small sedimentary ridges, which survive only in small depressions in the shelf that are protected from iceberg-keel erosion (Fig. 4c).

At the sides of some shallow banks, lateral ridges are present at the top of relatively steeper slopes that mark the limits of adjacent cross-shelf troughs (Fig. 5). The curvilinear ridges are up to about $50 \mathrm{~m}$ high and extend tens of kilometres along the trough sides, and can be present on either one or both sides of a given trough (Ottesen et al. 2016). The ridges show little penetration on sub-bottom profiler records and, therefore, are probably made up of diamictic debris (Ottesen et al. 2005a).

A number of distinctive glacitectonic landforms, similar to that in Figure $6 \mathrm{f}$, have also been identified on the shallow banks of the Norwegian shelf (Sættem 1990; Ottesen et al. 2005a; Rise et al. 2016. These landforms appear to have a paired geomorphology, with a depression and accompanying sedimentary mound of relatively equal proportions - hence the term 'hill-hole' pairs (e.g. Moran et al. 1980). Sometimes the hills have tapering streamlined edges in the direction of former ice flow (Rise et al. 2016).

\section{Interpretation}

Sets of small transverse-to-flow ridges (Fig. 4) are proposed to have formed at the ice margin during slow retreat of a grounded ice-sheet across the relatively shallow shelf-banks (Dowdeswell et al. 2008). Many modern tidewater glaciers undergo short-term winter readvances, during which small ridges are pushed up at the terminus, followed by summer retreat as iceberg calving increases uninhibited by winter sea-ice buttressing (Boulton 1986; Ottesen \& Dowdeswell 2006). Where the grounded ice-sheet terminus halts for longer periods, larger moraine ridges may form.

The relatively large ridges at the lateral edges of shallow banks (Fig. 5) are interpreted to be formed subglacially at the shear-zone between fast-flowing ice streams occupying cross-shelf troughs and slower moving ice on the adjacent shallower banks - they are known as ice stream lateral shear-margin moraines (Stokes \& Clark 2002; Ottesen et al. 2005a, 2016). Similar elongate ridges have been mapped at the lateral margins of terrestrial ice streams in Arctic Canada and interpreted as lateral shear-margin moraines (Dyke \& Morris 1988). It is at the shear zone between fast- and slow-flowing ice where these moraines are produced through the deformation of soft subglacial sediments (Stokes \& Clark 2002; Hindmarsh \& Stokes 2008).

Hill-hole pairs (Fig. 6f) are interpreted as subglacially produced glacitectonic landforms, whose ice-distal sedimentary hills mark the deposition of sediment that is temporarily frozen onto and entrained at the ice-sheet bed to produce the ice-proximal depressions. Hillhole pairs are often located on shallow banks where ice is likely to have been relatively thin, slow-flowing and sometimes frozen to the bed, entraining debris by freeze-in (Moran et al. 1980; Ottesen et al. 2005a). Freezing of water onto the base of a glacier may also drain excess pore water from fine-grained sediments and lead to overconsolidation and tectonism (Sættem 1990; Sættem et al. 1996). The sediment volumes entrained and transported during the formation of hill-hole pairs can reach several cubic kilometres (Rise et al. 2016).

A major problem for the interpretation of landforms and sediments on many high-latitude shelf-banks is that they are extensively reworked by the ploughing action of iceberg keels. The primary imprint of glacial activity may therefore be either modified (Fig. 4a) or, in extreme cases, almost completely destroyed (Fig. 4c) (e.g. Dowdeswell et al. 1993). The severity of iceberg-keel reworking of the geomorphic and stratigraphic record is dependent on bank water-depth, the keel depth of the icebergs themselves, and the mechanical properties of the substrate, together with the flux and duration of iceberg drift across the shelf.

Finally, it is notable that few indications of channelised subglacial meltwater flow, or sedimentary bodies relating to deposition from subglacial drainage systems (e.g. Dowdeswell et al. 2015), are found on the sedimentary banks offshore of either the Norwegian shelf or that west of Svalbard, in contrast to the relative frequency of meltwater channels in crystalline bedrock further inshore. It may be that, where the ice on shallow banks remains unfrozen at the bed, water travels mainly within the sediments by Darcian processes rather than forming subglacial channels. A possible exception is a sedimentary depocentre of about $60 \mathrm{~km}^{2}$ and $1-2 \mathrm{~km}^{3}$ in volume (located at 
$\left.65^{\circ} 05^{\prime} \mathrm{N}, 7^{\circ} 15^{\prime} \mathrm{E}\right)$ that appears likely to represent water-delivered debris from a high-magnitude flood that may be related to ice-dammed lake drainage, mass-wasting, or sediment loading and dewatering on the mid-Norwegian shelf during the Late Weichselian glaciation (Dowdeswell et al. 2016).

\section{Landforms in fjords and at fjord mouths with limited ice flux}

\section{Description}

At the entrance to some fjords, sets of relatively large arcuate moraines are found on the innermost shelf (Fig. 6b), especially where the shelf is relatively flat and cross-shelf troughs are poorly developed or absent (Ottesen \& Dowdeswell 2009). The ridges are up to $30 \mathrm{~m}$ high and spaced hundreds of metres apart (Fig. 6b, e). Sets of such arcuate ridges, best developed at the mouth of Raudfjorden, are present offshore of three fjords in northwest Spitsbergen (Ottesen \& Dowdeswell 2009). These arcuate ridges are far from ubiquitous, however, and larger fjords which grade into major cross-shelf troughs are instead typified by linear to curvilinear streamlined sedimentary landforms, known as mega-scale glacial lineations (Clark 1993), that are orientated in the direction of past ice flow (e.g. Ottesen et al. 2005a, 2005b, 2007).

In fjords occupied by ice supplied from relatively small ice-sheet drainage basins, and therefore having a limited ice flux and flow velocity, a mix of transverse- and parallel-to-flow submarine landforms is often present (Fig. 6b) (Ottesen \& Dowdeswell 2009). These landforms include sets of small transverse ridges often a few metres in height and spaced a few hundred metres apart (Fig. 6a). In addition, where bedrock outcrops occur, crag-and-tail landforms with rock cores and sedimentary tails hundreds or more metres in length are also present (Fig. 6b). Occasionally, the small transverse ridges appear to cross-cut the crag-and-tails, making them the younger landform. Where deeper basins occur within fjords, they are often infilled by fined-grained sediment, exhibiting a smooth seafloor underlain by acoustically stratified sediments (Ottesen \& Dowdeswell 2009). Examples include Smeerenburghfjorden and Raudfjorden in northwest Spitsbergen (Fig. 6a, b), where the limited ice flux comes only from a small interior catchment (Ottesen \& Dowdeswell 2009). Finally, at the heads of many Spitsbergen fjords, a large ridge and large numbers of small transverse ridges occupy locations within a few kilometres of modern tidewater glaciers (Fig. 6a, c, d) (e.g. Ottesen \& Dowdeswell 2006; Burton et al. 2016).

\section{Interpretation}

Arcuate moraines, formed immediately beyond fjord mouths (Fig. 6b), are interpreted to represent the geometry of a slowly retreating, but still active ice margin as it exits and spreads out from confining fjord walls onto the shelf. Arcuate moraines of several tens of metres in height would probably take decades or longer to form and, hence, indicate that the ice front halted in such locations for relatively long periods during deglaciation. The shape of these moraines is reminiscent of lobe-shaped piedmont glaciers and their associated recessional moraines that spread out from confining valley walls in modern terrestrial environments in, for example, Arctic Canada.

On fjord floors, the small transverse-to-flow ridges are interpreted as retreat moraines formed during fjord deglaciation (Fig. 6a-b), and are similar to the small ridges present on shelf-banks (Fig. 4) that are produced at the grounded terminus of a retreating ice terminus during brief winter readvances (Boulton 1986; Ottesen \& Dowdeswell 2006). Crag-and-tails, with their streamlined tails orientated in the direction of past ice flow (Fig. 6b), indicate the presence and flow direction of active ice. The occasional cross-cutting of crag-and-tails by small retreat moraines also suggests active ice in the fjord prior to deglacial retreat. Where the fjord floor is flat and smooth, often in bedrock-defined basins, fine-grained sediment with a laminated acoustic appearance is often found, probably deposited by rain-out from turbid meltwater plumes of suspended sediment derived from adjacent tidewater glaciers (Powell 1990; Ottesen \& Dowdeswell 2009; Dowdeswell et al. 2015). This is the Holocene muddy fill, with occasional iceberg-delivered dropstones, typical of many Spitsbergen fjords (e.g. Elverhøi et al. 1983; Sexton et al. 1992).

Finally, tidewater glaciers at many fjord heads underwent readvances of a few kilometres during the Little Ice Age (LIA) of the past few hundred years which terminated about a century ago on Svalbard (Werner 1993). These recent readvances and subsequent Twentieth Century retreat have produced large terminal moraines and further sets of small retreat moraines in inner-fjord settings that are still being generated at grounded tidewater glacier termini today (Fig. 6a) (Burton et al. 2016), sometimes in association with retreat after glacier surge advances (Ottesen \& Dowdeswell 2006; Ottesen et al. 2008; Flink et al. 2015).

\section{Discussion: inter-ice stream landforms and a schematic model}

The submarine glacier-influenced landforms described from the relatively shallow shelf-banks of the western Norwegian and Svalbard margins can be combined into a schematic landform-assemblage model (Fig. 7). The model illustrates an inter-ice stream landform assemblage that encompasses a whole sedimentary system. This includes the uppermost continental slope and shelf edge, reached by the full-glacial Eurasian Ice Sheet, the relatively shallow but extensive shelf-banks, and the adjacent fjords where, in the Svalbard case, many fjord heads are still occupied by tidewater glaciers.

A principal feature of the inter-ice stream glacial landform-assemblage model is that many of the submarine landforms are orientated transverse to the direction of past ice flow (Fig. 7). This is the case for shelf-edge moraines and the hummocky crest and depression belts that often accompany them (Fig. 2), arcuate fjord-mouth moraines (Fig. 6b) and recently deposited LIA terminal moraines (Fig. 6a), as well as the many sets of smaller transverse moraines found in both shelf and fjord settings (Figs. 4, 6). Ice-stream lateral shear-margin moraines run parallel to the edges of shallow banks where they descend into cross-shelf troughs (Fig. 5), marking the interface between former fast- and slow-flowing ice. By contrast, glacitectonically formed hill-hole pairs provide some elements of sedimentary streamlining and orientation in the direction of past ice flow on shelf-banks (Fig. 6f), along with occasional subdued streamlined glacial lineations (Ottesen \& Dowdeswell 2009), and streamlined crag-and-tails in fjords (Fig. 6b).

The inter-ice stream landform-assemblage model appears quite different when compared with a similar schematic model for an icestream landform-assemblage (Fig. 7). The latter is composed mainly of parallel-to-flow streamlined glacial sedimentary lineations, including mega-scale glacial lineations, that characterise sedimentation beneath ice streams in cross-shelf troughs (Fig. 7). These streamlined landforms are produced by the deformation of soft diamictic debris that forms the ice-stream beds (e.g. Alley et al. 1986; Dowdeswell et al. 2004; Ó Cofaigh et al. 2005). Beyond the shelf edge, trough-mouth fans are major depocentres for the large flux of glacial sediments delivered to ice-stream margins (Vorren et al. 1998). Glacigenic-debris flows remobilise this diamictic material on the upper slope to provide major building blocks for fan progradation (Fig. 7) (King et al. 1996; Vorren et al. 1998; Dowdeswell \& Siegert 1999). By contrast, the uppermost slope beyond shallower shelf-banks receives less glacial sediment delivery and iceberg ploughmarks and relatively subdued mass-wasting features are present (Fig. 3). 
In the Amundsen Sea Embayment offshore of West Antarctica, Klages et al. (2013, 2016) also report a shelf-bank assemblage that contrasts greatly with the streamlined linear features characteristic of former Antarctic ice-stream beds (e.g. Livingstone et al. 2012, 2016). Klages et al. $(2013,2016)$ mapped recessional moraines, hill-hole pairs and isolated sediment rafts, in additional to large areas of transverse-to-flow ribbed moraines (Hättestrand 1997) and crevasse-squeeze ridges that indicate ice stagnation, which they suggest are related to relatively thin and slow-moving ice which may be intermittently frozen to the bed. This work supports the distinctiveness of an inter-ice stream landform assemblage on both Arctic and Antarctic glacier-influenced margins where ice flow is slow and flux is low between fast-flowing ice streams.

\section{References}

ALLEY, R.B., BLANKENSHIP, D.D. BENTLEY, C.R. \& ROONEY, S.T. 1986. Deformation of till beneath Ice Stream B, West Antarctica Nature, 322, 5759.

BAMBER, J.L., VAUGHAN, D.G. \& JOUGHIN, I. 2000. Widespread complex flow in the interior of the Antarctic Ice Sheet. Science, 287, 1248-1250.

BATCHELOR, C.L. \& DOWDESWELL, J.A. 2014. The physiography of High Arctic cross-shelf troughs. Quaternary Science Reviews, 92, 68-96.

BATCHELOR, C.L. \& DOWDESWELL, J.A. 2015. Ice-sheet grounding-zone wedges (GZWs) on high-latitude continental margins. Marine Geology, 363, $65-92$.

BENN, D.I., WARREN, C.R. \& MOTTRAM, R.H. 2007. Calving processes and the dynamics of calving glaciers. Earth-Science Reviews, 82, $143-179$.

BINDSCHADLER, R.A., KING, M.A., ALLEY, R.B., ANANDAKRISHNAN, S. \& PADMAN, L. 2003. Tidally controlled stick-slip discharge of a West Antarctic ice stream. Science, 301, 1087-1089.

BOULTON, G.S. 1986. Push-moraines and glacier-contact fans in marine and terrestrial environments. Sedimentology, 33, $667-698$.

BURTON, D.J., DOWDESWELL, J.A., HOGAN, K.A. \& NOORMETS, R. 2016. Little Ice Age retreat moraines in Kollerfjorden, northwest Spitsbergen. In DOWDESWELL, J.A., CANALS, M., JAKOBSSON, M., TODD, B.J., DOWDESWELL, E.K. \& HOGAN, K.A. (eds), Atlas of Submarine Glacial Landforms: Modern, Quaternary and Ancient. Geological Society, London, Memoirs, 46, ???-???.

CLARKE, G.K.C. 1987. Fast glacier flow: ice streams, surging and tidewater glaciers. Journal of Geophysical Research, 92, 8835-8841.

CHRISTIANSON, K. PARIZEK, B.R., et al. 2013. Ice sheet grounding zone stabilization due to till compaction. Geophysical Research Letters, 40, 54065411.

CLARK, C.D. 1993. Mega-scale glacial lineations and cross-cutting ice-flow landforms. Earth Surface Processes and Landforms, 18, 1-19.

DOWDESWELL, J.A. \& ELVERHØI, A. 2002. The timing of initiation of fast-flowing ice streams during a glacial cycle inferred from glacimarine sedimentation. Marine Geology, 188, 3-14.

DOWDESWELL, J.A. \& SIEGERT, M.J. 1999. Ice-sheet numerical modeling and marine geophysical measurements of glacier-derived sedimentation on the Eurasian Arctic continental margins. Geological Society of America, Bulletin, 111, 1080-1097.

DOWDESWELL, J.A., VILLINGER, H., WHITTINGTON, R.J. \& MARIENFELD, P. 1993. Iceberg scouring in Scoresby Sund and on the East Greenland continental shelf. Marine Geology, 111, 37-53.

DOWDESWELL, J.A., Ó COFAIGH C. \& PUDSEY, C.J. 2004. Thickness and extent of the subglacial till layer beneath an Antarctic palaeo-ice stream. Geology, 32, 13-16.

DOWDESWELL, J.A., OTTESEN, D., EVANS, J., Ó COFAIGH, C. \& ANDERSON, J.B. 2008. Submarine glacial landforms and rates of ice-stream collapse. Geology, 36, 819-822.

DOWDESWELL, J.A., HOGAN, K.A., Ó COFAIGH, C., FUGELLI, E.M.G., EVANS, J. \& NOORMETS, R. 2014. Late Quaternary ice flow in a West Greenland fjord and cross-shelf trough system: submarine landforms from Rink Isbrae to Uummannaq shelf and slope. Quaternary Science Reviews, 92 , 292-309.

DOWDESWELL, J.A., HOGAN, K.A., et al. 2015. Sediment-rich meltwater plumes and ice-proximal fans at the margins of modern and ancient tidewater glaciers: observations and modelling. Sedimentology, 62, 1665-1692.

DOWDESWELL, J.A., OTTESEN, D., RISE, L. \& FORSBERG, C.F. 2016. A fan-like sedimentary depocentre on outer Haltenbanken, mid-Norwegian shelf. In DOWDESWELL, J.A., CANALS, M., JAKOBSSON, M., TODD, B.J., DOWDESWELL, E.K. \& HOGAN, K.A. (eds.) Atlas of Submarine Glacial Landforms: Modern, Quaternary and Ancient. Geological Society, London, Memoirs, 46, ???-???.

DYKE, A.S. \& MORRIS, T.S. 1988. Drumlin fields, dispersal trains and ice streams in Arctic Canada. Canadian Geographer 32, 86-90.

ELVENES, S. \& DOWDESWELL, J.A. 2016. Possible 'lift-off moraines' at grounded ice-sheet margins, North Norwegian shelf edge. In DOWDESWELL, J.A., CANALS, M., JAKOBSSON, M., TODD, B.J., DOWDESWELL, E.K. \& HOGAN, K.A. (eds.), Atlas of Submarine Glacial Landforms: Modern, Quaternary and Ancient. Geological Society, London, Memoirs, 46, ???-???.

ELVERHØI, A., LØNNE, Ø. \& SELAND, R. 1983. Glaciomarine sedimentation in a modern fjord environment, Spitsbergen. Polar Research, 1, 127-149.

FLINK, A.E., NOORMETS, R., et al. 2015. The evolution of a submarine landform record following recent and multiple surges of Tunabreen glacier, Svalbard. Quaternary Science Reviews, 108, 37-50.

GUDMUNDSSON, H. 2006. Fortnightly variations in the flow velocity of Rutford Ice Stream, West Antarctica. Nature, 444, $1063-1064$.

HÄTTESTRAND, C. 1997. Ribbed moraines in Sweden - distribution pattern and palaeoglaciological implications. Sedimentary Geology, 111, 41-56.

HINDMARSH, R.C.A. \& STOKES, C.R. 2008. Formation mechanisms for ice-stream lateral shear margin moraines. Earth Surface Processes and Landforms, 33, 612-626.

HUGHES, A.L.C., GYLLENCREUTZ, R., LOHNE, Ø.S., MANGERUD, J. \& SVENDSEN, J.I. 2016. The last Eurasian ice sheets - a chronological database and time-slice reconstruction, DATED-1. Boreas, 45, 1-45.

KING, E.L., SEJRUP, H.P., HAFLIDASON, H., ELVERHØI, A. \& AARSETH, I. 1996. Quaternary seismic stratigraphy of the North Sea Fan: glacially-fed gravity flow aprons, hemipelagic sediments, and large submarine slides. Marine Geology, 130, 293-315.

KLAGES, J.P., KUHN, G. et al. 2013. First geomorphological record and glacial history of an inter-ice stream ridge on the West Antarctic continental shelf. Quaternary Science Reviews, 61, 47-61.

KLAGES, J.P., KUHN, G. et al. 2016. An inter-ice stream ridge glacial landform assemblage in the eastern Amundsen Sea Embayment, West Antarctica. In DOWDESWELL, J.A., CANALS, M., JAKOBSSON, M., TODD, B.J., DOWDESWELL, E.K. \& HOGAN, K.A. (eds.) Atlas of Submarine Glacial Landforms: Modern, Quaternary and Ancient. Geological Society, London, Memoirs, 46, ???-???.

LIVINGSTONE, S.J., Ó COFAIGH, C., STOKES, C.R., HILLENBRAND, C.-D., VIELI, A. \& JAMIESON, S.S.R. 2012. Antarctic palaeo-ice streams Quaternary Science Reviews, 111, 90-128.

LIVINGSTONE, S.J., Ó COFAIGH, C., HOGAN, K.A. \& DOWDESWELL, J.A. 2016. Submarine glacial-landform distribution along an Antarctic Peninsula palaeo-ice stream: a shelf-slope transect through the Marguerite Trough system $\left(66^{\circ}\right.$ to $\left.70^{\circ} \mathrm{S}\right)$. In DOWDESWELL, J.A., CANALS, M., JAKOBSSON, M., TODD, B.J., DOWDESWELL, E.K. \& HOGAN, K.A. (eds.) Atlas of Submarine Glacial Landforms: Modern, Quaternary and Ancient. Geological Society, London, Memoirs, 46, ???-???.

MORAN, S.R., CLAYTON, L., HOOKE, R.L., FENTON, M.M. \& ANDRIASHEK, L.D. 1980. Glacier-bed landforms of the Prairie region of North America. Journal of Glaciology, 25, 457-476.

Ó COFAIGH, C., DOWDESWELL, J.A., et al. 2005. Flow dynamics and till genesis associated with a marine-based Antarctic palaeo-ice stream. Quaternary Science Reviews, 24, 709-740.

OTTESEN, D. \& DOWDESWELL, J.A. 2006. Assemblages of submarine landforms produced by tidewater glaciers in Svalbard. Journal of Geophysical Research, 111, F01016, doi:10.1029/2005JF000330. 
OTTESEN, D. \& DOWDESWELL, J.A. 2009. An inter-ice stream glaciated margin: submarine landforms and a geomorphic model based on marinegeophysical data from Svalbard. Geological Society of America Bulletin 121, 1647-1665.

OTTESEN, D., DOWDESWELL, J.A. \& RISE, L. 2005a. Submarine landforms and the reconstruction of fast-flowing ice streams within a large Quaternary ice sheet: the 2500-km-long Norwegian-Svalbard margin $\left(57^{\circ}-80^{\circ} \mathrm{N}\right)$. Geological Society of America Bulletin 117, $1033-1050$.

OTTESEN, D., RISE, L., KNIES, J, OLSEN, L. \& HENRIKSEN, S. 2005b. The Vestfjorden-Traenadjupet palaeo-ice stream drainage system, midNorwegian continental shelf. Marine Geology, 218, 175-189.

OTTESEN, D., DOWDESWELL, J.A., LANDVIK, J.Y. \& MIENERT, J., 2007. Dynamics of the Late Weichselian ice sheet on Svalbard inferred from highresolution sea-floor morphology. Boreas, 36, 286-306.

OTTESEN, D., DOWDESWELL. J.A., et al. 2008. Submarine landforms characteristic of glacier surges in two Spitsbergen fjords. Quaternary Science Reviews, 27, 1583-1599.

OTTESEN, D., DOWDESWELL, J.A., RISE, L., THORSNES, T. \& BELLEC, V. 2016. Lateral ice-stream shear-margin moraines on North Norwegian shelves. In DOWDESWELL, J.A., CANALS, M., JAKOBSSON, M., TODD, B.J., DOWDESWELL, E.K. \& HOGAN, K.A. (eds.) Atlas of Submarine Glacial Landforms: Modern, Quaternary and Ancient. Geological Society, London, Memoirs, 46, ???-???

POWELL, R.D., 1990. Glacimarine processes at grounding-line fans and their growth to ice-contact deltas. In DOWDESWELL, J.A. \& SCOURSE, J.D. (eds), Glacimarine Environments: Processes and Sediments. Geological Society, London, Special Publication, 53, 53-73.

RIGNOT, E. \& KANAGARATNAM, P. 2006. Changes in the velocity structure of the Greenland Ice Sheet. Science, 311, 986-988.

RISE, L., BELLEC, V.K., OTTESEN, D., BOE, R. \& THORSNES, T. 2016. Hill-hole pairs on the Norwegian continental shelf. In DOWDESWELL, J.A., CANALS, M., JAKOBSSON, M., TODD, B.J., DOWDESWELL, E.K. \& HOGAN, K.A. (eds.) Atlas of Submarine Glacial Landforms: Modern, Quaternary and Ancient. Geological Society, London, Memoirs, 46, ???-???.

SÆTTEM, J. 1990. Glaciotectonic forms and structures on the Norwegian continental shelf: observations, processes and implications. Norsk Geologisk Tidsskrift, 70, 81-94.

SÆTTEM, J., RISE, L., ROKOENGEN, K. \& BY, T. 1996. Soil investigations offshore mid Norway: A case study of glacial influence on geotechnical properties. Global and Planetary Change, 12, 271-285.

SEXTON, D.J., DOWDESWELL, J.A., SOLHEIM, A. \& ELVERHØI, A. 1992. Seismic architecture and sedimentation in north-west Spitsbergen fjords. Marine Geology, 103, 53-68.

STOKES, C.R. \& CLARK, C.D. 2001. Palaeo-ice streams. Quaternary Science Reviews, 20, 1437-1457.

STOKES, C.R. \& CLARK. C.D. 2002. Ice stream shear margin moraines. Earth Surface Processes and Landforms, 27, $547-558$.

SVENDSEN, J.., ALEXANDERSON, H. et al. 2004. Late Quaternary ice sheet history of northern Eurasia. Quaternary Science Reviews, 23, $1229-1271$.

VORREN, T.O., LABERG, J.S., et al. 1998. The Norwegian-Greenland Sea continental margins: morphology and Late Quaternary sedimentary processes and environment. Quaternary Science Reviews, 17, 273-302.

WERNER, A. 1993. Holocene moraine chronology, Spitsbergen, Svalbard: lichenometric evidence for multiple Neoglacial advances in the Arctic. The Holocene, 3, 128-137.
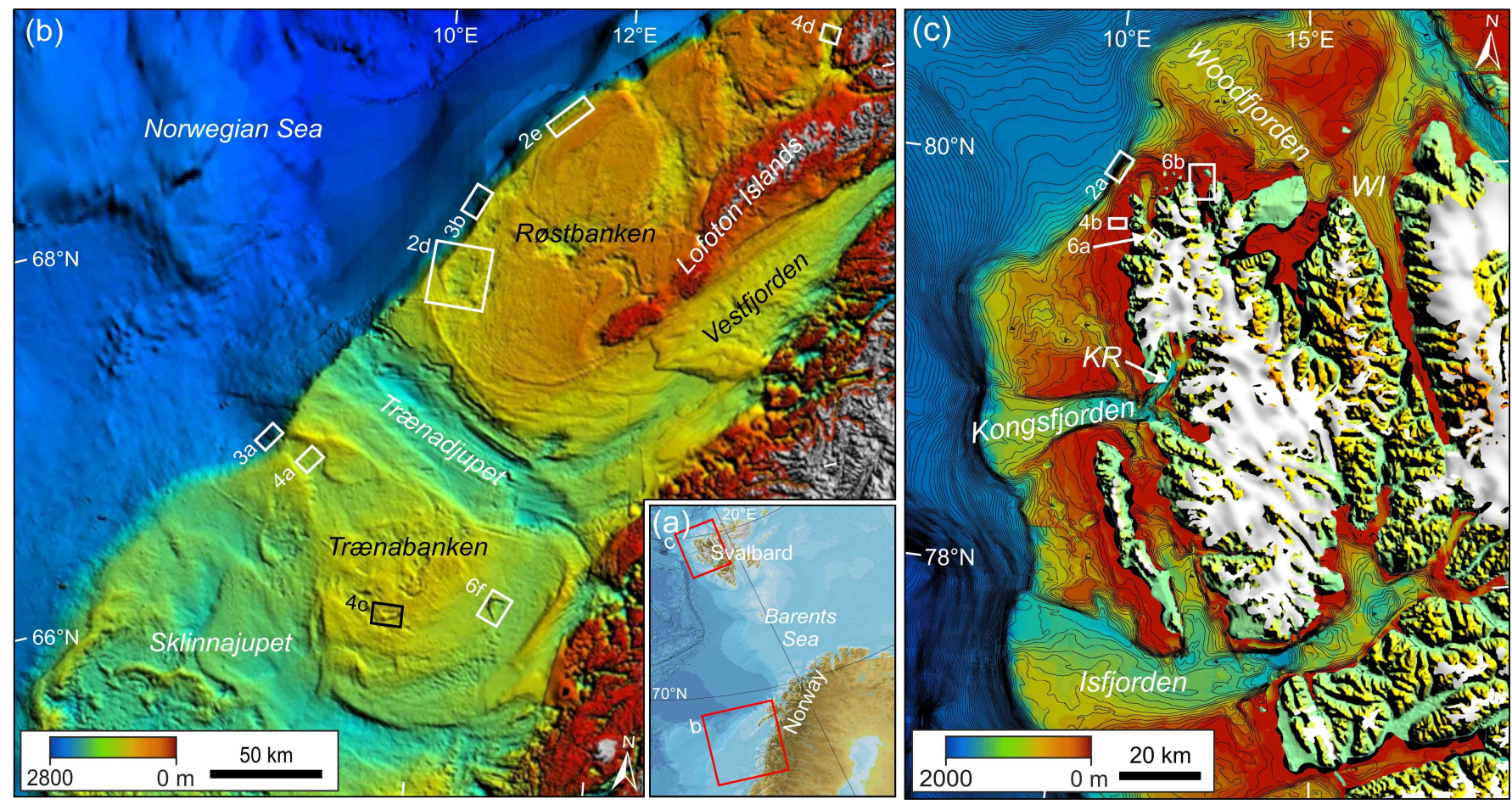

Fig. 1. (a) Location of the study areas offshore of Norway and Svalbard (red boxes; map from IBCAO v. 3.0). Bathymetric data showing the pattern of shallow banks and intervening cross-shelf troughs offshore of (b) northwestern Norway and (c) northwestern Spitsbergen are illustrated. WI $=$ Wijdefjorden, $\mathrm{KR}=$ Krossfjorden, MA is Magdalenefjorden . 

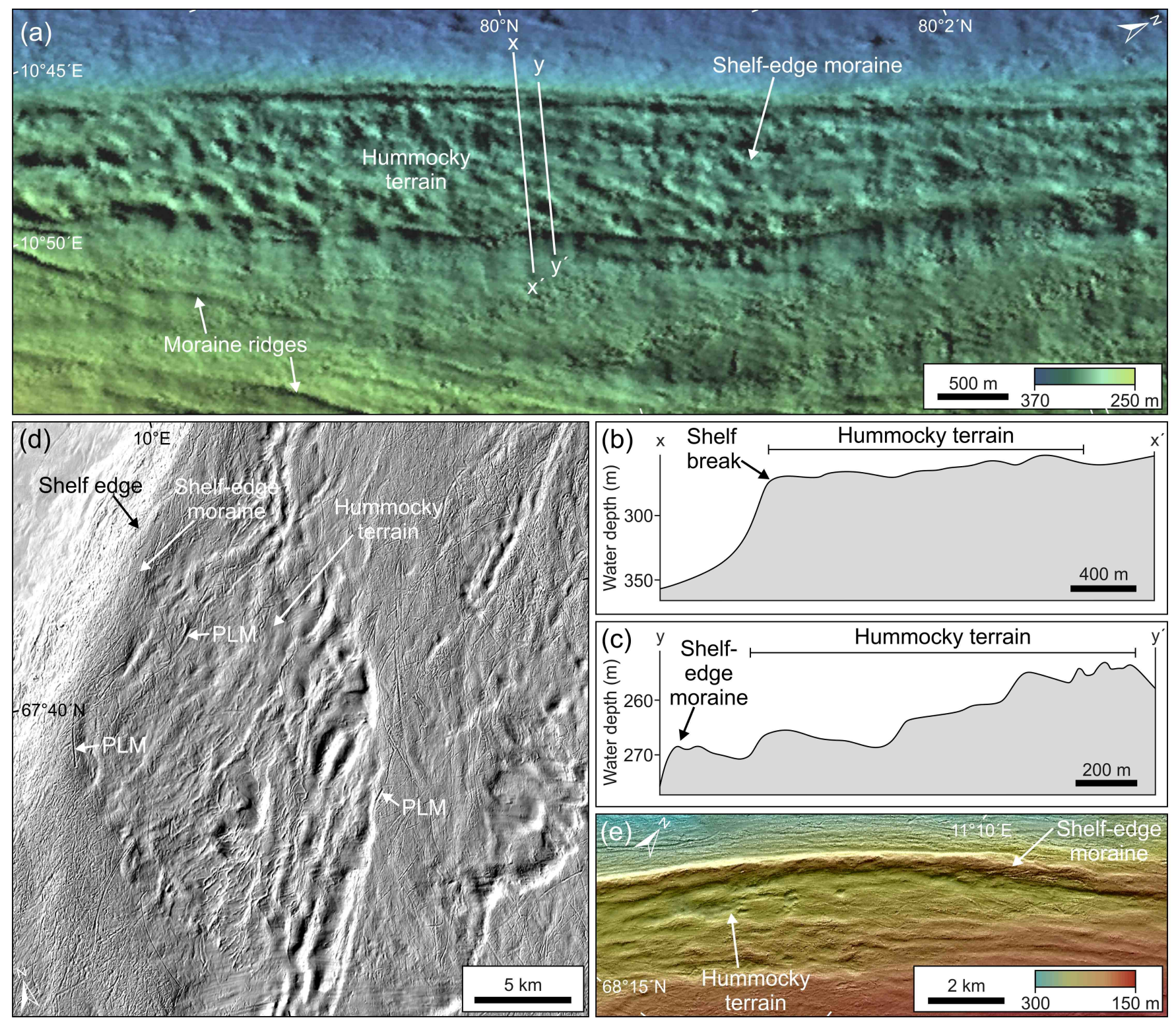

Fig. 2. Submarine landforms on the shelf edge adjacent to shallow banks between ice streams west of Norway and Spitsbergen. (a) Shelfedge moraines, marking the limit of Late Weichselian grounded ice northwest of Spitsbergen, with hummocky terrain and recessional moraines on the outer shelf. (b) and (c) Bathymetric profiles across the outermost shelf. VE x 8 and 18. (d) and (e) Shelf-edge moraines and belts of hummocky topography close to the shelf edge of Røstbanken west of Lofoten (located in Fig. 1b), interpreted as possible liftoff moraines. Acquisition system Kongsberg EM1002. Frequency $95 \mathrm{kHz}$. Grid-cell size $5 \mathrm{~m}$. In (d) the hummocky landforms have been affected by some iceberg ploughing. PLM = iceberg ploughmark.
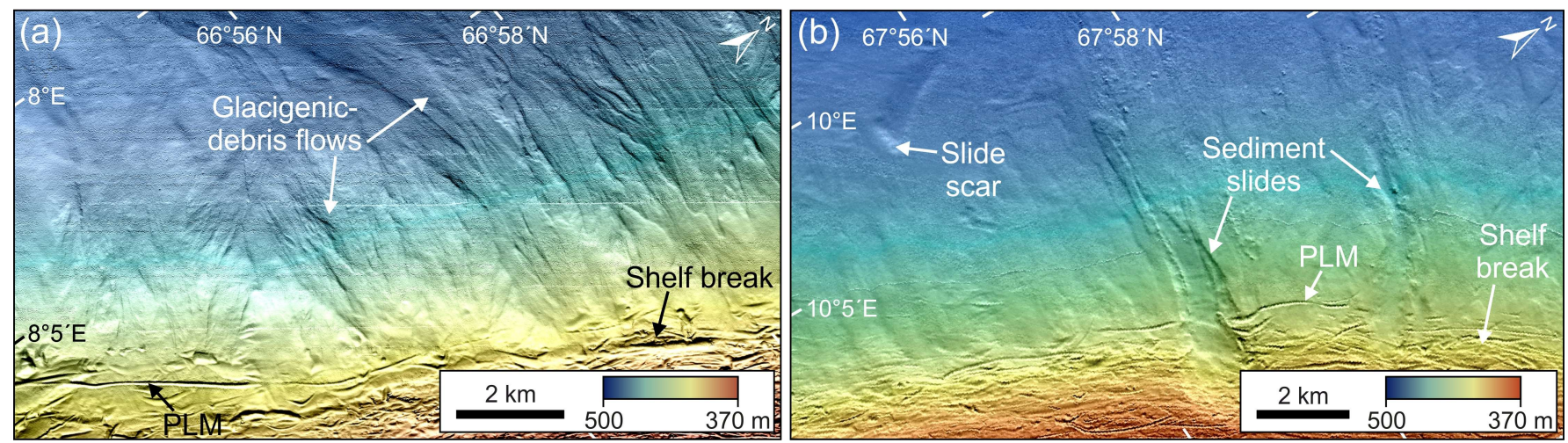

Fig. 3. (a) The uppermost continental slope offshore Trænabanken, with shelf-edge iceberg ploughmarks (PLM) and glacigenic-debris flows originating from the Trænadjupet and Sklinnadjupet systems. (b) Relatively minor mass-wasting features on the uppermost slope beyond Røstbanken, which cross-cut older ploughmarks. Acquisition system Kongsberg EM1002. Frequency 95 kHz. Grid-cell size 5 m. 

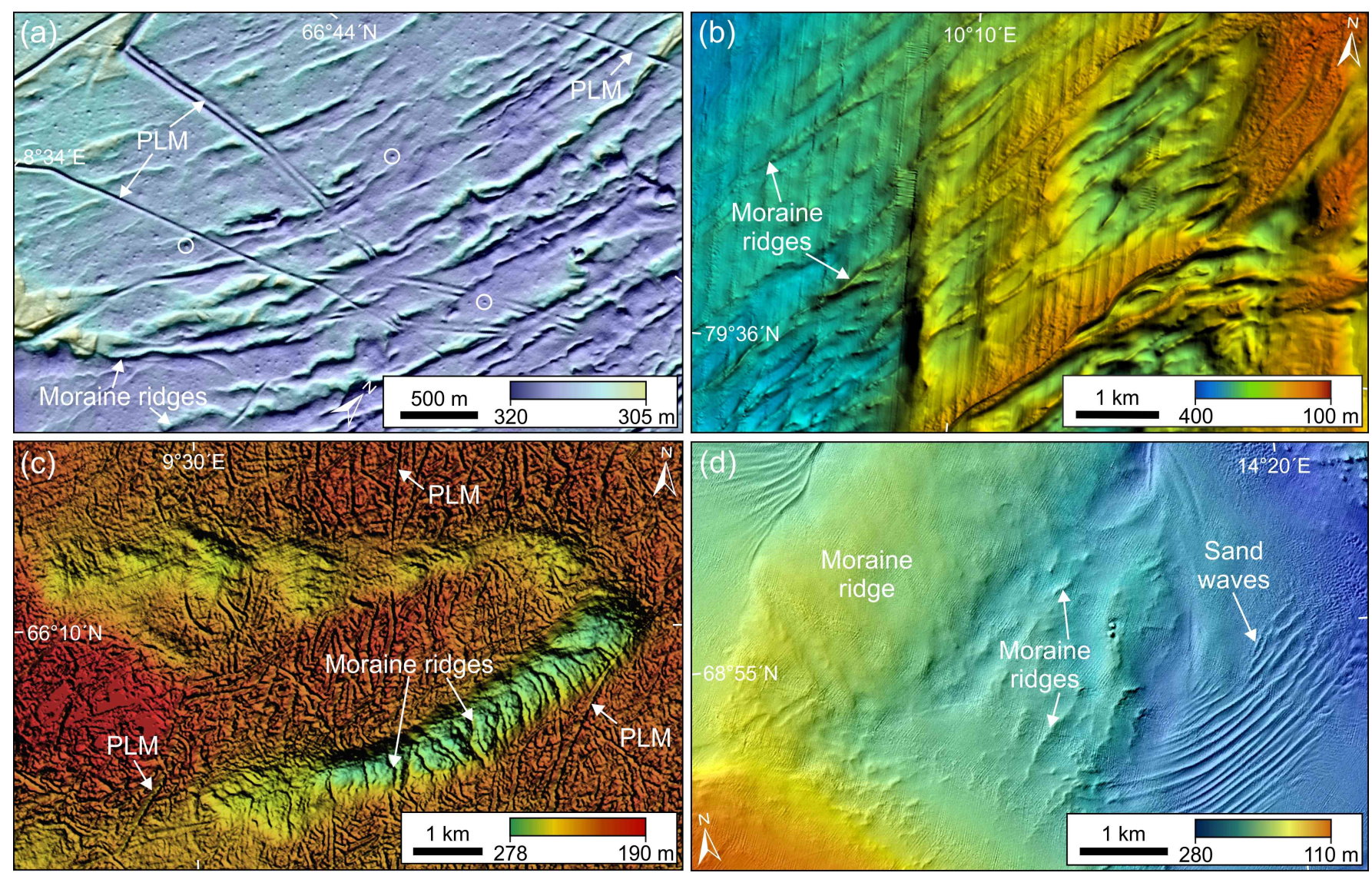

Fig. 4. Sets of relatively small transverse moraine ridges indicative of ice-marginal retreat across the shallow banks on the Norwegian and Spitsbergen shelves. (a) Set of sub-parallel moraine ridges on outer Trænabanken, cross-cut by occasional iceberg ploughmarks (PLM). Small pockmarks are also visible (circled). Acquisition system Kongsberg EM1002. Frequency $95 \mathrm{kHz}$. Grid-cell size $5 \mathrm{~m}$. (b) Moraine ridges on the northwest Spitsbergen shelf. Acquisition system Kongsberg EM1002. Frequency $95 \mathrm{kHz}$. Grid-cell size $10 \mathrm{~m}$. (c) Moraine ridges preserved in a depression on the otherwise intensively iceberg ploughed Trænabanken. Data from the seafloor reflector of a 3D seismic cube. Grid-cell size $10 \mathrm{~m}$. (d) Moraine ridges becoming partly buried by current-delivered sediments in the Hola area outside Vesterålen. Acquisition system Kongsberg EM1002. Frequency 95 kHz. Grid-cell size 5 m. 

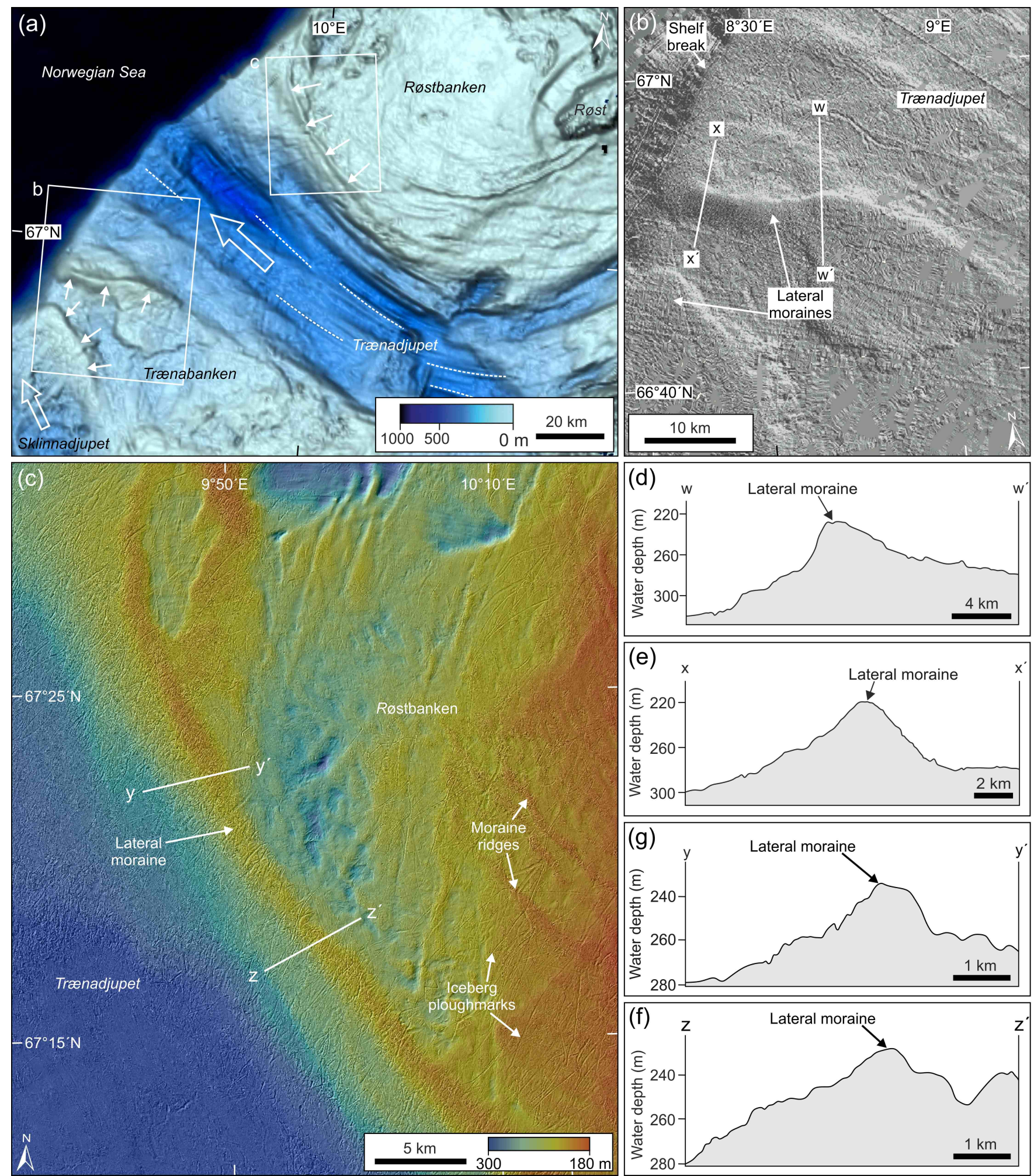

Fig. 5. (a) Lateral shear-margin moraines marking the boundary between fast- and slower-moving ice in Trænadjupet and the adjacent Trænabanken (south) and Røstbanken (north). (b) Close-up of lateral moraines at the southern lateral margin of Trænadjupet. From OLEX bathymetry data. (c) Close-up of a lateral moraine at the northern lateral margin of Trænadjupet. (d) and (e) Bathymetric profiles across the lateral moraine at the southern lateral margin of Trænadjupet. VE x 70 and 80. (f) and (g) Bathymetric profiles across the lateral moraine at the northern lateral margin of Trænadjupet. VE x 40 and 38. Acquisition system Kongsberg EM1002. Frequency 95 kHz. Grid-cell size $5 \mathrm{~m}$. 

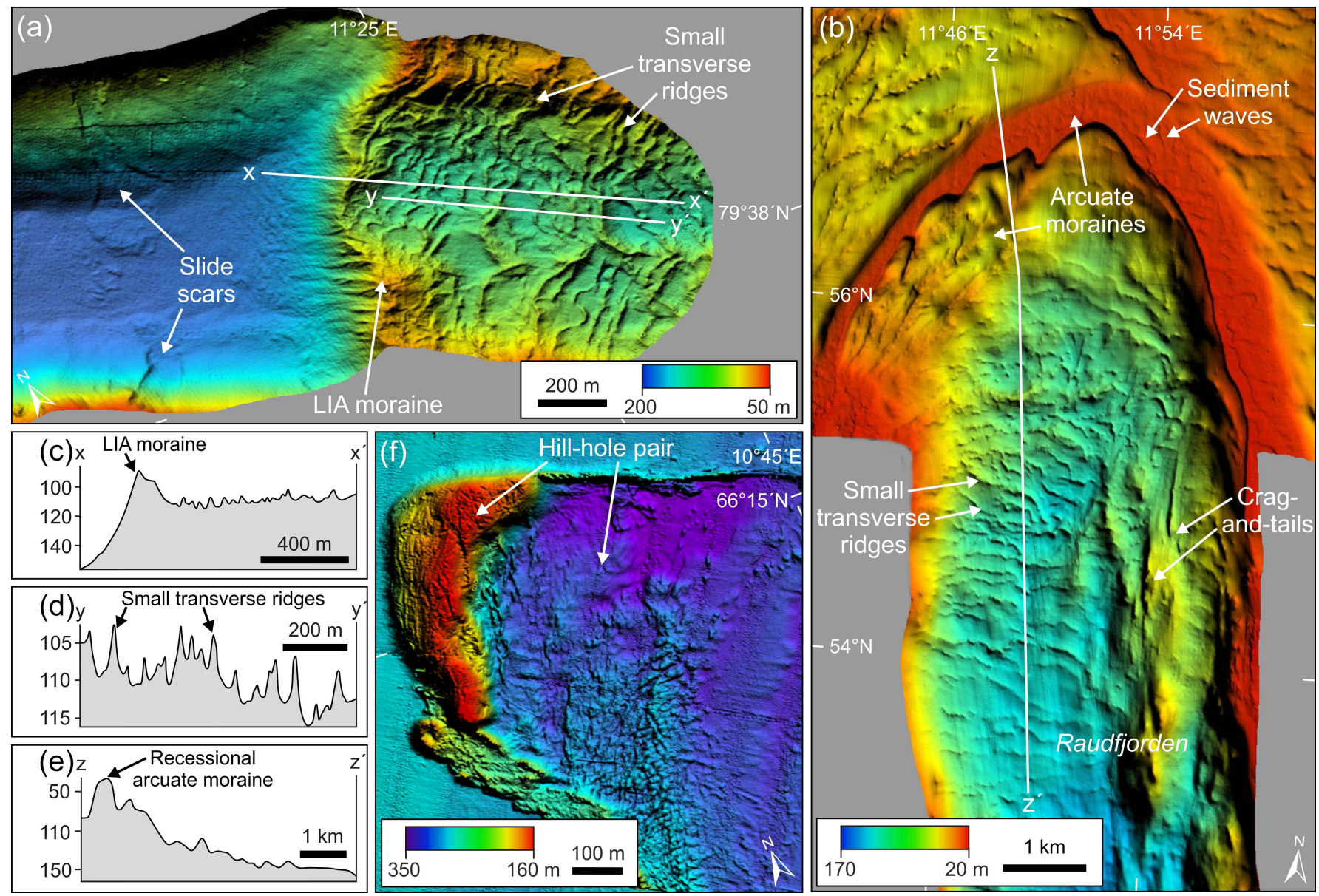

Fig. 6. Other landforms on inter-ice stream shallow-shelf banks and in fjords (located in Fig. 1b, c). (a) Inner fjord glacial landforms produced during LIA advance and subsequent Twentieth Century retreat in Smeerenburgfjorden, northwest Spitsbergen. (b) Arcuate moraines formed on the continental shelf at the mouth of Raudfjorden, as ice spreads out from confining fjord walls. Also shown are small moraine ridges orientated transverse to past ice flow and crag-and-tails streamlined in the direction of past ice flow (modified from Ottesen \& Dowdeswell 2009). (c) to (e) Bathymetric profiles down fjord long-axes showing moraine-ridge dimensions. VE x 7, 23 and 17, respectively. (f) Hill-hole pair from Trænabanken west of Norway, probably formed close to a thin ice-sheet margins during deglaciation. Acquisition system Kongsberg EM1002. Frequency $95 \mathrm{kHz}$. Grid-cell size $5 \mathrm{~m}$.

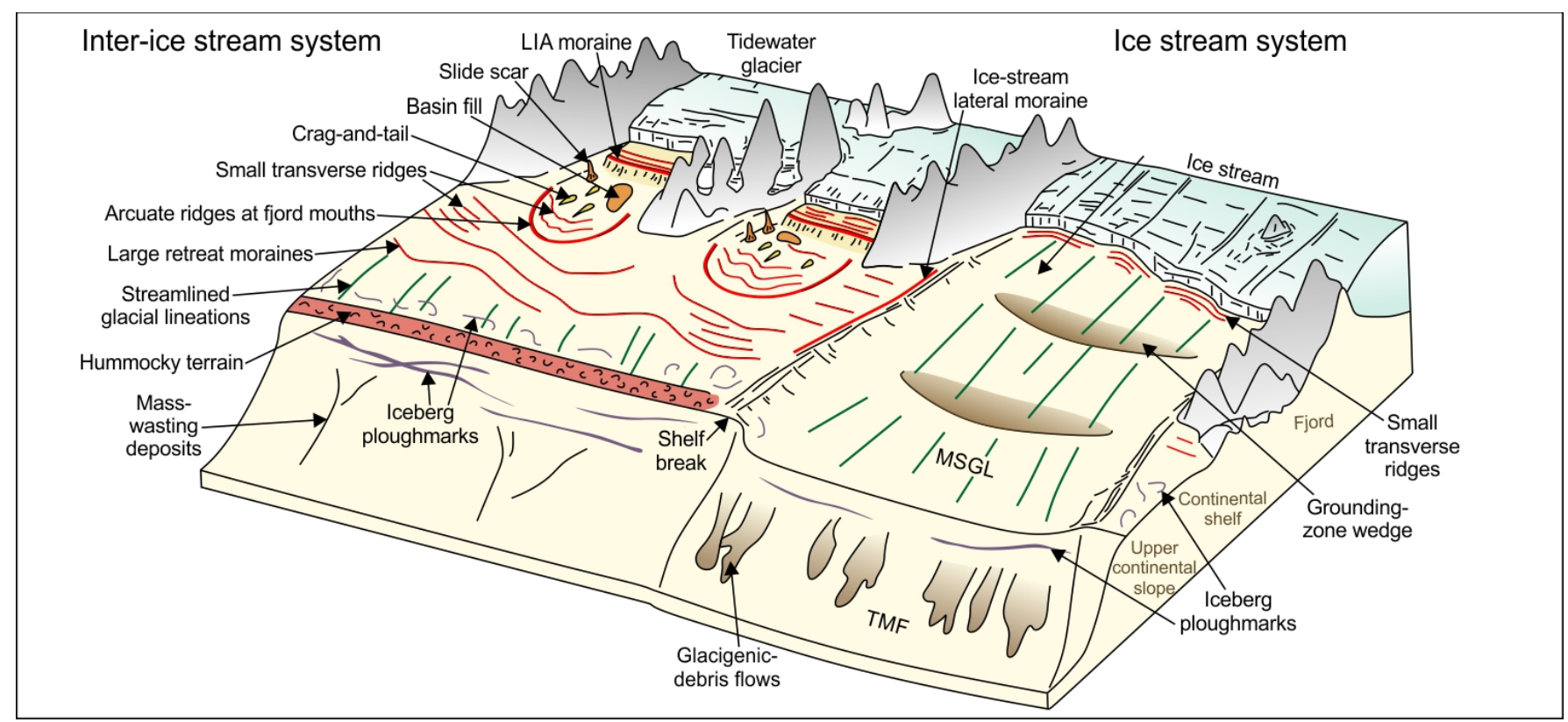

Fig. 7. Summary block diagrams of the suite of submarine landforms on the seafloor of inter-ice stream shallow banks and cross-shelf troughs formerly occupied by ice streams (modified from Ottesen \& Dowdeswell 2009). 